\title{
Image Driven Hydrological Components Based Fish Habitability Modeling in Riparian Wetlands Triggered by Damming
}

\section{Swades Pal}

University of Gour Banga

Rumki Khatun ( $\nabla$ rumkikhatun5@gmail.com )

University of Gour Banga

\section{Research Article}

Keywords: Damming, Hydrological modification, Fishing habitat suitability, Rule based decision tree model and Hydrological components

Posted Date: July 26th, 2021

DOI: https://doi.org/10.21203/rs.3.rs-651761/v1

License: (c) (i) This work is licensed under a Creative Commons Attribution 4.0 International License. Read Full License

Version of Record: A version of this preprint was published at Wetlands on January 1st, 2022. See the published version at https://doi.org/10.1007/s13157-021-01521-7. 


\section{Abstract}

Assessing fish habitability in pursuance of damming for some selected fishes in wetland of IndoBangladesh barind tract using hydrological ingredients like hydro-period, water depth, and water presence consistency is major focus of the present study. Rule based decision tree modeling has been applied for integrating aforesaid hydrological parameters to find out habitat suitability for some selected fishes like carp fishes, shrimps, tilapia and cat fishes both for pre-dam and post-dam periods. From this work it is highlighted that damming has accelerated the rate of wetland deterioration in forms of hydrological flow alteration i.e. inconsistency in water presence has increased, hydro-duration became shortened and water depth has attenuated. From the model it is very clear that a small proportion area was considered to be good fish habitat (16.54-39.90\%) in pre-dam period, but after damming almost all parts have become least suitable for fish habitability. Field survey has confirmed that fishing quantity, growing rate of fishes was higher in pre-dam situation but it is reduced gradually during post-dam period. Image driven hydrological parameters to model fish habitability is a new approach but important parameters like food availability, water quality parameters could also be incorporated in order to get better result.

\section{Introduction}

Wetland, a natural capital, occupies $6 \%$ of world's geographical land (Mitsch et al., 2013). It provides different provisional, regulating, habitat and cultural services of socio-ecological importance (Wang et al., 2020). Wetland serves as one of the major means of livelihood for developing nations like India, Bangladesh where a huge part of population is highly dependent on primary activities like fishing, agriculture, dairy farming, cattle ranching, etc. Since fish is the most demanding provisioning service found in wetlands, fishermen communities are dependent on these. However, wetland conversion at a fast rate is threatening for their livelihood. Among various factors, agricultural expansion in wetland areas is a major threat for wetland transformation (Saha and Pal, 2019). Hydrological modification through damming plays pivotal role in alteration of wetland characters (Dudgeon, 2000). Attenuation of water depth has occurred due to water diversion through canals, over lifting of water for various purposes. Reduction of flow in downstream is responsible for causing hydrological drought in rivers (Wen et al., 2011; Araujo et al., 2016). Gain and Giupponi (2014) has figured out flow reduction by $52 \%$ in Ganga River due to construction of Farakka Barrage, Talukdar and Pal (2018) has found reduction in Punarbhava river by $41 \%$, Uday Kumar and Jayakumar (2019) has found out the reduction of flow by $30 \%$ in Krishna River. Flow reduction causes losing of tie channels for riparian wetlands which is responsible for depletion of water availability (Pal and Sarda, 2020). Eco-hydrological deficit is acute in some wetlands of Barind tract of Indo-Bangladesh (Saha and Pal, 2019); Talukdar and Pal, 2020).

A specific environmental gradient of some elements are necessary for fish survival; each component has different effects on the survival of fishes to which fish can grow at different levels of coziness. Among several essential hydro-ecological components, water depth is a major one which affects fish survival crucially (Hosen et al., 2019). Certain range of depth is required for economic growth for different fish species; this is mainly because of food availability and environmental suitability (Baras and Lucas, 2001; 
Mouton et al., 2007). MPEDA \& NACA Manual (2015); Hosen et al (2019) have estimated the suitable depth of survival of some fishes. For instances, Hosen et al (2019) has identified depth of water between 1.2 to $2.8 \mathrm{~m}$ is suitable for carp fishes (Labeo Rohita, Gibelion Catla, Cirrhinus Mrigala), 1 to $2 \mathrm{~m}$ for Tilapia fish, 1 to $3 \mathrm{~m}$ for Shrimp fish, more than $2.14 \mathrm{~m}$ for catfishes (MPEDA \& NACA Manual, 2015) etc. Hydrological modification is directly linked with water availability reduction and depletion of water depth which in turn affects fish storage and declining quality of fish habitability. As huge proportion of people is dependent on fishing, uncertainty for livelihood has been arising among fishermen due to hydroecological alteration. So this is a matter of great concern. Therefore, the present paper has tried to assess impact of flow reduction on hydrological elements and how their changes can influence fish habitat for some particular fishes in the studied region.

For the fulfillment of aforesaid objectives it is of immense necessity to model the alteration patterns of hydrological regimes for e.g. depth of water, wetland size, water presence consistency, hydro-duration in the concerned wetland. To find out suitable fish habitability these parameters are very important, but field data collection from such wider wetland tract is a major challenge. Consistency of water presence in seasonal wetlands of the Barind tract has been extracted through satellite imageries data by few previous researchers (Debanshi and Pal, 2020; Khatun et al., 2021). Water depth has been extracted by using indices like normalized difference water index (NDWI) by field depth calibration (Debanshi and Pal, 2020). Due to damming inconsistency of water presence has increased; water depth has reduced at a wide extent in this type of seasonal wetland. Beside these, hydro-period is an important hydrological determinant of fish habitability since patterns of wetlands are strongly connected with fish phenology. Hydro-duration is affected by damming in a negative way which affects availability of fish species and their productivity. It is quite cumbersome to mapping hydro-period by field investigation in such a wider area of wetland. So in this study a new approach has been adopted to model hydro-period by using multidate image data in each year. By combining all these three hydrological parameters, fish habitat suitability can be assessed in a precise way.

Habitat suitability modeling has been applied by various scholars worldwide with different approaches. Among the several habitat suitability model, physical habitat simulation model (Boove, 1982) is worldwide applied model to modeling fish habitability by using water depth and flow velocity as parameters. Main function of this model is to link up different physical variables of flow regime to water richness by bi-variate or multi-variate statistics. Mouton et al. (2006) applied this model in Zwalm river in Belgium. Another popular method is Habitat Suitability Index which was developed in early 1980s. The index is calculated on the basis of several parameters like availability of foods, natural fish behavior like spawning, seasonal behavioral pattern, flood inundation areas. The index is calculated using HABITAT modeling in MATLAB toolbox by considering water depth and flow velocity in Abras de Mantiquilla wetland in Ecuador (Mieles et al, 2019). Similarly, HSI (Habitat Suitability Index) was calculated for Jinsha river basin in upper reaches of Yangtze river (Zhang et al, 2018). Apart from these, a widely used approach is fuzzy logic based habitat suitability index. By taking water depth, flow velocity and dominant substrate fuzzy logic was set and applied in Zwalm river, Belgium (Mouton et al, 2006) for various riverine fishes. But from various literatures it has been found that most of the fish habitat modeling is done on 
riverine ecosystems. Very few studies have been documented about fish habitat suitability measurement in wetland across the world. Novelty of the work lies in the fact that no works has been done yet on wetland so far based on only hydrological components like hydro-period, satellite driven WPF, calibrated water depth. In this work both individual parameter and combine parameter specific habitat suitability analysis has been done. However, it is very unique to apply rule based decision tree to integrate suitable fish habitat modeling by comprising only hydrological parameters. As Punarbhaba is highly modified hydrologically due to damming and large portions of it belongs to floodplain wetlands, it has been taken as a study area.

\section{Materials And Methods \\ 2.1 Study area}

Punarbhaba river basin covers about $5265.93 \mathrm{~km}^{2}$ in Barind tract of India-Bangladesh. Before neotectonic movement this river was hydrological potential when Teesta river was used to flow through it. After beheading from Teesta the river lost its main source of water, it has been turned into hydrological peripheral one (Rashid and Sultan-Ul-Islam, 2014). Such geohydrological phenomenon causes drastic changes in hydro-ecological setup in this river and it has turned into rain fed rivers from perennial river. Beside that Komardanga dam was constructed over Dhepa river, a major tributary of Punarbhaba river, in 1992 in Birganj, which is another major reason for hydrological flow alteration (Fig. 1). Hydrological modification has a serious impact on wetland environment as they are solely dependent on river water and rainfall. This region experiences sub humid climate with alternating wet and dry spells. About $80 \%$ of rainfall occurs on monsoon with annual average rainfall of about $1500 \mathrm{~mm}$. High temperature $\left(>35^{\circ} \mathrm{C}\right)$ associated with high evapotranspiration leads to squeezing of perennial wetland in summer season (March to May). The region is densely populated and most of its residents are dependent on agriculture and fishing. People of villages like Rohanpur, Gomastapur, Chowdala, Mokrampur which falls in downstream catchment are highly dependent on fishing for their livelihood. So it is a matter of great concern to detect changing faces of wetland hydrology in general and fish habitability in particular.

\subsection{Materials}

USGS Earth explorer is most important source to do time series analysis of land use and monitor its dynamic changes ((Nguyen et al., 2018). A detail of data source has been mentioned in Table 1. 
Table 1

Database of the study

\begin{tabular}{|c|c|c|c|c|}
\hline $\begin{array}{l}\text { Data } \\
\text { Types }\end{array}$ & $\begin{array}{l}\text { Available } \\
\text { Years }\end{array}$ & Description & Purpose & Sources \\
\hline $\begin{array}{l}\text { Landsat } \\
4-5 \mathrm{TM}\end{array}$ & $\begin{array}{l}1991- \\
2012\end{array}$ & $\begin{array}{l}\text { Path/Row: } \\
139 / 43, \\
\text { Resolution } \\
30 \mathrm{~m} \text {, Band } \\
7\end{array}$ & $\begin{array}{l}\text { Water consistency } \\
\text { mapping, water depth } \\
\text { mapping and hydro- } \\
\text { duration mapping }\end{array}$ & $\begin{array}{l}\text { United States Geological } \\
\text { Society(USGS) Earth Explorer } \\
\text { Website } \\
\text { (https://earthexplorer.usgs.gov) }\end{array}$ \\
\hline $\begin{array}{l}\text { Landsat } \\
8 \mathrm{OLI}\end{array}$ & $\begin{array}{l}2013- \\
2020\end{array}$ & $\begin{array}{l}\text { Path/Row: } \\
139 / 43, \\
\text { Resolution } \\
30 \mathrm{~m} \text {, Band } \\
11\end{array}$ & $\begin{array}{l}\text { Water consistency } \\
\text { mapping, water depth } \\
\text { mapping and hydro- } \\
\text { duration mapping }\end{array}$ & $\begin{array}{l}\text { United States Geological } \\
\text { Society(USGS) Earth Explorer } \\
\text { Website } \\
\text { (https://earthexplorer.usgs.gov) }\end{array}$ \\
\hline
\end{tabular}

\subsection{Methods}

\subsubsection{Wetland mapping}

Several numbers of indices like Normalized Difference Water Index (NDWI), Modified Normalized Difference Water Index (MNDWI), Re-Modified Normalized Difference Water Index (RMNDWI) for extracting water bodies from the satellite images are available. These indices are used for mapping and monitoring surface water bodies like reservoirs, rivers, wetlands, lakes etc. Since different indices are suitable for distinct areas, Das and Pal (2018) has suggested NDWI is the best suited for barind tract of Indo-Bangladesh region. Mcfeeters (1996) for the first time proposed NDWI and it is computed by Eq. 1. NDWI value ranges between -1 to 1 . Positive value signifies water body, greater positive value indicates more water depth and vice versa.

$$
N D W I=\frac{\text { bgreen }-b_{N R R}}{\text { bgreen }+b_{N R}}
$$

Where

$b_{\text {green }}$ is the green band (Band 2 for TM and Band 3 for OLI)

$b_{N I R}$ is the near infrared band (Band 4 for TM and Band 5 for OLI)

Wetland maps for recent years (since 2016) have been validated by employing Kappa Coefficient (K) (Eq. 2). 100-150 ground control points (GCPs) have been taken for those years to validate wetland maps. $\mathrm{K}$ values range between 0.77 to 0.86 for these years indicating strong association to wetland map with ground truth. 


$$
k=\frac{N \sum_{i-1}^{r} x i i-\sum_{i-1}^{r}(x i+* x i+i)}{N^{2}-\sum_{i=1}^{r}\left(x i+*^{*} x i+i\right)}
$$

Where, $\mathrm{N}$ refers to total number of pixels; $r$ refers to number of rows in the matrix; $X i i$ equal to number of observations in row $\mathrm{i}$; and column ii and $\mathrm{xi}+$ and $\mathrm{x}+\mathrm{i}$ refer to as the marginal totals for row $\mathrm{i}$ and column i.

\subsubsection{Measuring hydrological modifications 2.3.2.1 Hydro-period mapping}

Time-span of water-stagnation in a specific wetland for a specific year signifies hydro-period for that particular year. Based on hydro-period,wetlands are classified into perennial, seasonal and ephemeral. NDWI monthly images in a year have been assigned to binary form i.e. 1 for wetland and 0 for nonwetland in order to compute hydro-period model for both pre-dam and post-dam periods. Then the monthly maps have been summed up to prepare final hydro-duration map.

\subsubsection{Wetland water depth mapping}

Water depth mapping has been extracted by calibrating NDWI following Debanshi and Pal (2020), Khatun el al (2021). Calibration of NDWI images (1991 for pre-dam and 2020 for post-dam period) has been done using water depth of 2020. The regression equation $(y=a+b x)$ between NDWI values and water depth data of the selected sites has been used for calibrating the average NDWI images of both pre and postdam sites.

\subsubsection{Water presence consistency mapping}

Water presence frequency (WPF) signifies magnitude of water appearance in a specific wetland in a particular period of time (Borro et al. 2014; Debanshi and Pal, 2019). Each time series NDWI images have been assigned to 1 for wetland and 0 for non-wetland for both pre and post-dam periods. Those binary images have been summed up distinctly for pre-dam and post-dam and divided by total number of selected years (Eq. 4 ). WPF in percentage ranges between $0-100 \%$, where 0 indicates low water consistency and 100 means high water consistency.

$$
W P F_{p}=\frac{\sum_{n=1}^{l} X_{j}}{N}
$$

where WPFp is the calculated water presence frequency for $p$ pixel, $X j$ is the frequency of $j$ th pixel in image $X$ having water appearance, and $N$ is the number of year taken. 


\subsubsection{Integration of Hydrological components for analyzing habitat suitability for fishing}

Several factors are responsible for fish habitat determination, but in this study major hydrological parameters like WPF, hydro-period, water depth have been taken into consideration for fish habitability measurement. Before integrating the parameters it is important to investigate suitable depth for fish survival, ideal range of hydro-duration and of course frequency of water presence in a particular wetland. Ideal range of water depth for fish survival has been figured out from existing literatures for some selected fishes like Carps (Labeo Rohita, Cirrhinus Mrigala, Gibelion Catla), catfish, shrimps and tilapia fishes in concerned flood plain rich wetlands. It can be considered that longer duration of growing period or longer water stagnation may be beneficiary for fish phenology to be developed as well as fruitful from economic point of view (Freeman et al., 2001). Besides that, potentiality of perennial wetland for good fish habitability is far greater than ephemeral or seasonal ones (Hosen et al., 2019). A wetland with high WPF is more reliable fishing ground than low WPF. Natural fish seeding requires frequently inundated wetland from surrounding perennial rivers and wetlands. It is beneficiary for fishermen to seed fishes on perennial water area. Considering the facts, high WPF is most suitable for fishing ground. Rule based decision tree (RBDT) has been applied to obtain fish habitability modeling by incorporating such parameters based on the set logics. RBDT uses declarative rules as input to define a particular decision tree. First step is attribute selection criteria by which inputs are implemented in the model. In this study, to fulfillment our purposes three hydrological parameters i.e. water depth, hydro-period, water presence consistency have taken into consideration both for pre-dam and post-dam period. The set rule for habitat suitability is hydro-period $>9$ months, WPF $>67 \%$ and existence of optimum depth of survival of particular fish.

\section{Results}

\subsection{Wetland scenario in pre and post-dam periods}

Since the present study area is strongly influenced by amount of rainfall, wetland scenario of this region is highly fluctuating. Average wetland area between pre and post-dam period shows a significant difference. Significant reduction in wetland area has been observed from pre-dam ( $\left.149.26 \mathrm{~km}^{2}\right)$ to postdam period $\left(59.67 \mathrm{~km}^{2}\right)$. Kappa coefficient has been used to validate NDWI index based wetland mapping. Range of computed $\mathrm{K}$ values for the years varied from 0.77 to 0.86 indicating strong agreement between ground reality and wetland map. Due to lack of reference data no images of pre-dam period has been validated but it is very clear that if recent data validates NDWI images, then pre-dam data are likely to be validated.

\subsection{Characters of wetland hydrological attributes}

In pre-dam period, wetlands with high hydro-period (>9 months) was $92.35 \mathrm{~km}^{2}$ (61.57\% to total wetland area) which is reduced to $20.65 \mathrm{~km}^{2}$ (13.77\% to total wetland area) in post-dam period. On the contrary 
the area under low hydro-period has increased in post-dam period. In case of WPF, high WPF (>67\%) was $70.85 \mathrm{~km}^{2}(47.23 \%$ to total wetland area) in pre-dam period and it is reduced to $42.28 \mathrm{~km} 2(71.66 \%$ to total wetland area) in post-dam period. Contrarily, area under low WPF $(<33 \%)$ have inflated by $20 \%$ in between pre and post-dam periods. This is a serious issue to the existing ecosystem in general and fish ecology in particular. Analysis of water depth also signifies the same trend of deterioration. In pre-dam period, $58.51 \mathrm{~km}^{2}$ or $(39.01 \%)$ area was there where depth of water was $>3.37 \mathrm{~m}$. but in post-dam period no wetland area is found within this depth category. In post-dam period entire wetland area has been converted into low water depth category $(<1.78 \mathrm{~m})$ (Table 2$)$. In spatial context, the degradation in terms of depth of water, WPF and hydro-duration, is clearly observable in the upper parts of the selected study area and fringe wetland (Fig. 2).

Table 2

Wetland area under different classes of the selected hydrological components

\begin{tabular}{|c|c|c|c|c|c|}
\hline \multirow[t]{2}{*}{ Parameters } & \multirow[t]{2}{*}{ Sub class } & \multicolumn{2}{|c|}{ Pre-dam } & \multicolumn{2}{|c|}{ Post-dam } \\
\hline & & $\begin{array}{l}\text { Area in } \\
\mathrm{km}^{2}\end{array}$ & $\begin{array}{l}\text { Area in } \\
\%\end{array}$ & $\begin{array}{l}\text { Area in } \\
\mathrm{km}^{2}\end{array}$ & $\begin{array}{l}\text { Area in } \\
\%\end{array}$ \\
\hline \multirow[t]{3}{*}{ WPF(\%) } & $\operatorname{Low}(<33)$ & 49.36 & 32.91 & 7.78 & 13.19 \\
\hline & Moderate(33-67) & 29.15 & 19.43 & 8.94 & 15.15 \\
\hline & $\operatorname{High}(>67)$ & 70.85 & 47.23 & 42.28 & 71.66 \\
\hline \multirow{3}{*}{$\begin{array}{l}\text { Hydro-period (No of } \\
\text { months) }\end{array}$} & Low $<3$ & 20.65 & 13.77 & 25.21 & 42.73 \\
\hline & Moderate 3-9 & 36.56 & 24.37 & 6.92 & 11.73 \\
\hline & High $>9$ & 92.35 & 61.57 & 3.34 & 5.66 \\
\hline \multirow[t]{3}{*}{ Water Depth (m) } & Low (.19-1.78) & 42.36 & 28.24 & 59 & 100 \\
\hline & $\begin{array}{l}\text { Moderate (1.78- } \\
3.37)\end{array}$ & 48.39 & 32.26 & 0 & 0 \\
\hline & High (3.37-4.96) & 58.51 & 39.01 & 0 & 0 \\
\hline
\end{tabular}

Thereby depth-area relation has been attempted to draw in regards to pre-dam and post-dam periods. Figure 3 depicts the frequency curves which indicate area under different water depth zones of wetlands for pre-dam and post-dam periods. It is evident from the curves that distribution pattern is positively and negatively skewed in pre and post-dam periods respectively. It signifies that greater depth was high during pre-dam period which become reverse during post-dam phenomenon.

\subsection{Habitat suitability in reference to in wetland depth}


Figure 4 portrays habitat suitability map for some fishes like carp fishes (Labeo Rohita, Gibelion Catla, Cirrihinus Mrigala), shrimp fishes, catfishes and tilapia fishes in reference to water depth for pre-dam and post-dam period. Each habitat suitability map has been categorized into three classes i.e. stress-deficit, optimum and stress-surplus conditions. The regions with suitable and habitable water depth is identified as optimum wetland area, whereas stress-deficit regions are areas with water depth below optimum range of survival and stress-surplus regions are areas with water depth above optimum range. It is evident from various literatures that vulnerability of deficit area is more than surplus area for ecosystem (Talukdar and Pal, 2017; Pal et al., 2019; Khatun et al., 2021). As it is already established that depth of water has deducted substantially after dam condition (Fig. 4), it is necessary to draw optimum depth for each fish both for pre-dam and post-dam period. For instance, area under optimum depth category for carp fishes, tilapia shrimp fishes and cat fishes were $30.04 \%, 37.60 \%, 35.36 \%$ and $61.71 \%$ respectively to total wetland area during pre-dam period but it has become almost nil during post-dam.

Table 3

Area under different survival range of water depth for some selected fishes in pre and postdam periods

\begin{tabular}{|c|c|c|c|c|c|}
\hline \multirow[t]{2}{*}{ Fishes } & \multirow[t]{2}{*}{ Water Depth(m) } & \multicolumn{2}{|l|}{ Pre-Dam } & \multicolumn{2}{|l|}{ Post-Dam } \\
\hline & & Area in $\mathrm{km}^{2}$ & Area in \% & Area in $\mathrm{km}^{2}$ & Area in \% \\
\hline \multirow[t]{3}{*}{ Carp fishes } & $<1.2$ & 38.39 & 25.64 & 59 & 100 \\
\hline & $1.2-2.8$ & 44.97 & 30.04 & 0 & 0 \\
\hline & $>2.8$ & 66.77 & 44.60 & 0 & 0 \\
\hline \multirow[t]{3}{*}{ Tilapia fishes } & $<1$ & 35.78 & 23.90 & 59 & 100 \\
\hline & $1-2$ & 56.28 & 37.60 & 0 & 0 \\
\hline & $>2$ & 58.02 & 38.76 & 0 & 0 \\
\hline \multirow[t]{3}{*}{ Shrimp fishes } & $<1$ & 34.68 & 23.17 & 59 & 100 \\
\hline & $1-3$ & 52.94 & 35.36 & 0 & 0 \\
\hline & $>3$ & 62.33 & 41.64 & 0 & 0 \\
\hline \multirow[t]{2}{*}{ Catfish } & $0.09-2.14$ & 57.47 & 38.39 & 59 & 100 \\
\hline & $>2.14$ & 92.38 & 61.71 & 0 & 0 \\
\hline
\end{tabular}

\subsection{Fish habitability modeling}

For each category of fishes, fish habitability modeling has been done using above mentioned hydrological parameters both for pre-dam and post-dam period (Fig. 5 ). Habitability of fishes has been categorized into suitable and less suitable condition using natural break method. From Fig. 5 it is 
observed that suitable habitat area was drastically reduced from pre-dam to post-dam period. Suitable habitat signifies wetland parts with WPF of higher frequency, hydro-period with longer duration and optimum water depth. Less suitable habitat means those parts of wetland where hydrological components are not in optimum state for fish habitability. In case of carp fishes, suitable area was 16.54 $\%$ in pre-dam period which is reduced by $7.35 \%$ and less suitable area was $83.73 \%$ which was increased by $92.65 \%$ in post-dam period. Similar situation exists for other mentioned fishes (Table 4). It indicates that habitat condition has been deteriorated in post-dam situation substantially. But poor habitat condition in post-dam period does not mean such fishes will not able to survive there. Physiologically the fishes have to be compromised with emerging hydrologically modified condition and it can hamper the growth of the fishes. Field investigation also shows this cruel reality. The fishermen stated that before 25-30 years ago, water availability was very high, large size fishes were very common, and frequency of fish catches was very high per each net. Their statement cross validates the computed hydrological components based fish habitat models.

Table 4

Area under habitat quality for some selected fishes in pre and post-dam periods

\begin{tabular}{|c|c|c|c|c|c|}
\hline Fish category & Habitat Condition & Pre-dam & & Post-dam & \\
\hline & & Area in $\mathrm{km}^{2}$ & Area in \% & Area in $\mathrm{km}^{2}$ & Area in \% \\
\hline \multirow[t]{2}{*}{ Carp fishes } & Suitable & 18.3 & 16.54 & 3.43 & 7.35 \\
\hline & Less suitable & 92.64 & 83.73 & 43.24 & 92.65 \\
\hline \multirow[t]{2}{*}{ Tilapia fishes } & Suitable & 17.67 & 15.97 & 2.42 & 5.19 \\
\hline & Less suitable & 93.27 & 84.30 & 44.25 & 94.81 \\
\hline \multirow[t]{2}{*}{ Shrimp fishes } & Suitable & 41.18 & 37.22 & 2.93 & 6.28 \\
\hline & Less suitable & 69.77 & 63.06 & 43.74 & 93.72 \\
\hline \multirow[t]{2}{*}{ Catfish } & Suitable & 44.14 & 39.90 & 3.43 & 7.35 \\
\hline & Less suitable & 66.8 & 60.38 & 43.24 & 92.65 \\
\hline
\end{tabular}

\section{Discussion}

It is very clear from the study that hydrological modifications in reference to hydro-period, water depth and WPF have been taken place noteworthy in post-dam situation. Those attributes have been altered steadily like inconsistency has increased in WPF, water depth has quenched, hydro-duration has shortened. About $65 \%$ wetland area has converted from wet to dry land and they are suffered from uncertainty of water availability, erratic hydrological condition. Such inconsistency of hydrological regimes is not favorable for rich aquatic ecosystem as well as for good fish habitability (Khatun et al., 
2021). Several factors are responsible for hydro-ecological modification of concerned wetlands for e.g. wetland fragmentation, reduction of flow in rivers due to damming, anthropogenic disturbance i.e. built up augmentation, agricultural encroachment, drastic changes in land use, etc (Wood et al., 2013; Fournier et al., 2018; Pal et al., 2020). A huge number of people are dependent on wetland for fishing to earn their livelihood. Due to damming, fishing grounds are fragmented and fish storages are reduced in quantity and quality which engrossed fishermen to shift into other occupations. Larger part of wetland was favorable for fishing before damming. But hydrological alteration and it's impact on wetland ecosystem causes deterioration of habitat quality for some fish species as studied here. Due to flow impoverishment ideal depth range for survival has been lost for most of the fishes. Flow attenuation is responsible for losing of tie channels and lateral detachment of river and wetland. Inundation frequency and magnitude causes reduction of water availability as well as crunching of nutrient supply and fish seeds, etc (Pal and Talukdar, 2019). Due to agricultural reclamation most of the tie channels have lost their existence. From this study it has found that hydro-period become narrower which affects growth of fishes and fish phenology. For this reason economic profitability of fishing ground has reduced widely.

Intensity of hydrological drought is more severe in summer due to absence of rainfall in sub humid tropical climate. Higher rate of evaporation causes reduction of water availability in perennial wetland and wider parts become dry (Pal and Talukdar, 2018b). Seasonal changes in depth have been recorded due to disparity in rainfall, as wetlands are highly dependent on rain. Under such circumstance, hydroperiod becomes narrower due to pursuance of damming (Khatun et al., 2021). Therefore it is clear that both natural and anthropogenic phenomenon causes habitat quality destruction. We can't change the natural rainfall regime but intervention on flow from human part could be revisited.

To identify favorable fishing habitat by integrating hydrological parameters using RBDT approach is very unique. As all the selected parameters have no definite optimum range of survival, it is very difficult to apply other very objective machine learning models which used to produce robust result. However this applied model is also appropriate here since two parameters like hydro-period and WPF has no definite quantitative optimum range of survival and these are set based on field experience and knowledge of the fishermen. This model provides a good opportunity to incorporate logic in categorical data set. In previous works, important parameters like water presence frequency and hydro-period has been ignored. Though there were some difficulties to include such parameters due to lack of spatial data, the present work intends to develop such parameters from satellite imageries calibrated field data. It will be helpful for future research. Instead of that, calibration process can be enhanced in future. In the present work only hydrological components have taken, apart from that there are other important parameters like water quality, nutrient availability, etc. which couldn't included because of shortage of spatial data. Certainly inclusion of these may enhance the precision of the model.

\section{Conclusion}

The study clearly exhibits that suitable fish habitability has been deteriorated in pursuance of damming in terms of water depth, water consistency and hydro-duration. Whether some fishes can withstand the 
altered situation, but some fishes can't survive in such situation. For instance, cat fishes can survive the modified hydrological situation. A new approach i.e. modeling of RBDT using hydrological components has been applied. Considering the success of the model, this work recommends for use this approach for fish habitability mapping. There are further scope for improving the model incorporating so many other relevant hydrological parameters where data will be available. Since hydrological modification is found as the major factor of habitat squeeze and deterioration for fishes, it is recommended to take proper measures to restore wetland for planning purposes. Water discharging policy through damming could be reviewed and redefined.

\section{Declarations}

\section{Ethical Approval}

Not applicable

\section{Consent to Participate}

Not applicable

\section{Consent to Publish}

Not applicable

\section{Authors Contributions}

Both the authors contributed to the study conception and design. Conceptualization; methodology designing; supervision; editing and reviewing were performed by Swades Pal. Data curation; investigation; formal analysis; validation; and writing of original draft were performed by Rumki Khatun. Both the authors read and approved the final manuscript.

\section{Funding}

No funds were received for this study.

\section{Competing Interests}

The authors declare that they have no competing interests

\section{Availability of data and materials}

The datasets used and/or analyzed during the current study are available from the corresponding author on reasonable request.

\section{Acknowledgement}


For this study, the authors would like to convey their gratitude to USGS for providing Landsat imageries.

\section{References}

1. Baras E, Lucas MC (2001) Impacts of man's modifications of river hydrology on the migration of freshwater fishes: a mechanistic perspective. International Journal of Ecohydrology Hydrobiology 1(3):291-304

2. Borro M, Morandeira N, Salvia M, Minotti P, Perna P, Kandus P (2014) Mapping shallow lakes in a large South American floodplain: a frequency approach on multitemporal Landsat TM/ETM data. J Hydrol 512:39-52

3. Bovee KD (1982) A guide to stream habitat analysis using the instream flow incremental methodology (Vol. 1). Western Energy and Land Use Team, Office of Biological Services, Fish and Wildlife Service, US Department of the Interior

4. Chakraborty R, Talukdar S, Basu T, Pal S (2018) Habitat identity crisis caused by the riparian wetland squeeze in Tangon River Basin, Barind Region, India. Spatial Information Research 26(5):507-516

5. Das RT, Pal S (2018) Investigation of the principal vectors of wetland loss in Barind tract of West Bengal. GeoJournal 83(5):1115-1131

6. de Araújo JC, Bronstert A (2016) A method to assess hydrological drought in semi-arid environments and its application to the Jaguaribe River basin, Brazil. Water Int 41(2):213-230

7. Debanshi S, Pal S (2020) Effects of water richness and seasonality on atmospheric methane emission from the wetlands of deltaic environment. Ecol Ind 118:106767

8. Debanshi S, Pal S (2020) Wetland delineation simulation and prediction in deltaic landscape. Ecol Ind 108:105757

9. Dudgeon D (2000) Large-scale hydrological changes in tropical Asia: prospects for riverine biodiversity: the construction of large dams will have an impact on the biodiversity of tropical Asian rivers and their associated wetlands. Bioscience 50(9):793-806

10. Fournier ML, Echeverría-Sáenz S, Mena F, Arias-Andrés M, de la Cruz E, Ruepert C (2018) Risk assessment of agriculture impact on the Frío River watershed and Caño Negro Ramsar wetland, Costa Rica. Environ Sci Pollut Res 25(14):13347-13359

11. Freeman MC, Bowen ZH, Bovee KD, Irwin ER (2001) Flow and habitat effects on juvenile fish abundance in natural and altered flow regimes. Ecological applications 11(1):179-190

12. Gain AK, Giupponi C (2014) Impact of the Farakka Dam on thresholds of the hydrologic flow regime in the Lower Ganges River Basin (Bangladesh). Water 6(8):2501-2518

13. Hosen MHA, Sarker K, Chhanda MS, Gupta N (2019) Effects of water depth on growth performance of Indian major carps at a poly culture system in Bangladesh. Int J Aquac Fish Sci 5(3):014-021

14. Khatun R, Talukdar S, Pal S, Kundu S (2021) Measuring dam induced alteration in water richness and eco-hydrological deficit in flood plain wetland. J Environ Manage 285:112157 
15. Kumar AU, Jayakumar KV (2020) Hydrological alterations due to anthropogenic activities in Krishna River Basin, India. Ecol Ind 108:105663

16. McFeeters SK (1996) The use of the Normalized Difference Water Index (NDWI) in the delineation of open water features. International journal of remote sensing 17(7):1425-1432

17. Mieles MGA (2019) Ecological Modelling of River-wetland Systems: A Case Study for the Abras de Mantequilla Wetland in Ecuador. CRC Press

18. Mitsch WJ, Bernal B, And Hernandez ME, 2013.Ecosystem services of wetlands

19. Mouton AM, Schneider M, Depestele J, Goethals PL, De Pauw N (2007) Fish habitat modelling as a tool for river management. Ecological engineering 29(3):305-315

20. Nguyen P, Ombadi M, Sorooshian S, Hsu K, AghaKouchak A, Braithwaite D, ... Thorstensen AR (2018) The PERSIANN family of global satellite precipitation data: A review and evaluation of products. Hydrol Earth Syst Sci 22(11):5801-5816

21. Pal S, Sarda R (2020) Damming effects on the degree of hydrological alteration and stability of wetland in lower Atreyee River basin. Ecol Ind 116:106542

22. Pal S, Talukdar S (2018) Drivers of vulnerability to wetlands in Punarbhaba river basin of IndiaBangladesh. Ecol Ind 93:612-626

23. Pal S, Talukdar S (2019) Impact of missing flow on active inundation areas and transformation of parafluvial wetlands in Punarbhaba-Tangon river basin of Indo-Bangladesh. Geocarto International 34(10):1055-1074

24. Pal S, Saha A, Das T (2019) Analysis of flow modifications and stress in the Tangon river basin of the Barind tract. International Journal of River Basin Management 17(3):301-321

25. Pal S, Talukdar S, Ghosh R (2020) Damming effect on habitat quality of riparian corridor. Ecol Ind 114:106300

26. Saha TK, Pal S (2019) Exploring physical wetland vulnerability of Atreyee river basin in India and Bangladesh using logistic regression and fuzzy logic approaches. Ecological indicators 98:251-265

27. Talukdar S, Pal S (2017) Impact of dam on inundation regime of flood plain wetland of punarbhaba river basin of barind tract of Indo-Bangladesh. International Soil Water Conservation Research 5(2):109-121

28. Talukdar S, Pal S (2020) Modeling flood plain wetland transformation in consequences of flow alteration in Punarbhaba river in India and Bangladesh. J Clean Prod 261:120767

29. Wang H, Song C, Song K (2020) Regional Ecological Risk Assessment of Wetlands in the Sanjiang Plain with Respect to Human Disturbance. Sustainability, 12(5), p.1974

30. Wen L, Rogers K, Ling J, Saintilan N (2011) The impacts of river regulation and water diversion on the hydrological drought characteristics in the Lower Murrumbidgee River, Australia. J Hydrol 405:382-391

31. Wood EF, Sivapalan M, Beven K, Band L (1988) Effects of spatial variability and scale with implications to hydrologic modeling. Journal of hydrology 102(1-4):29-47 
32. Zhang P, Yang Z, Cai L, Qiao Y, Chen X, Chang J (2018) Effects of upstream and downstream dam operation on the spawning habitat suitability of Coreius guichenoti in the middle reach of the Jinsha River. Ecol Eng 120:198-208

\section{Figures}

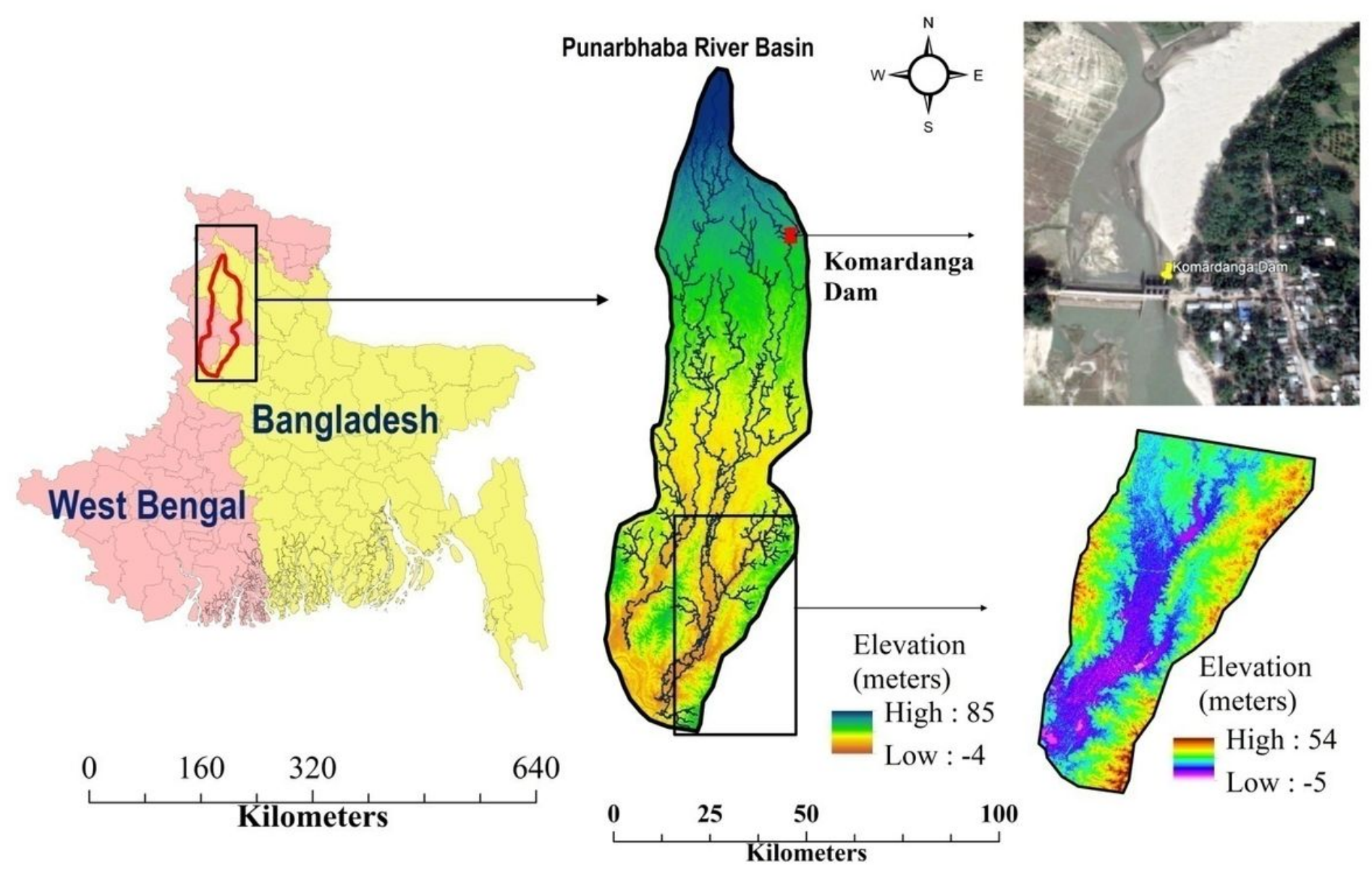

Figure 1

Location of Study Area 

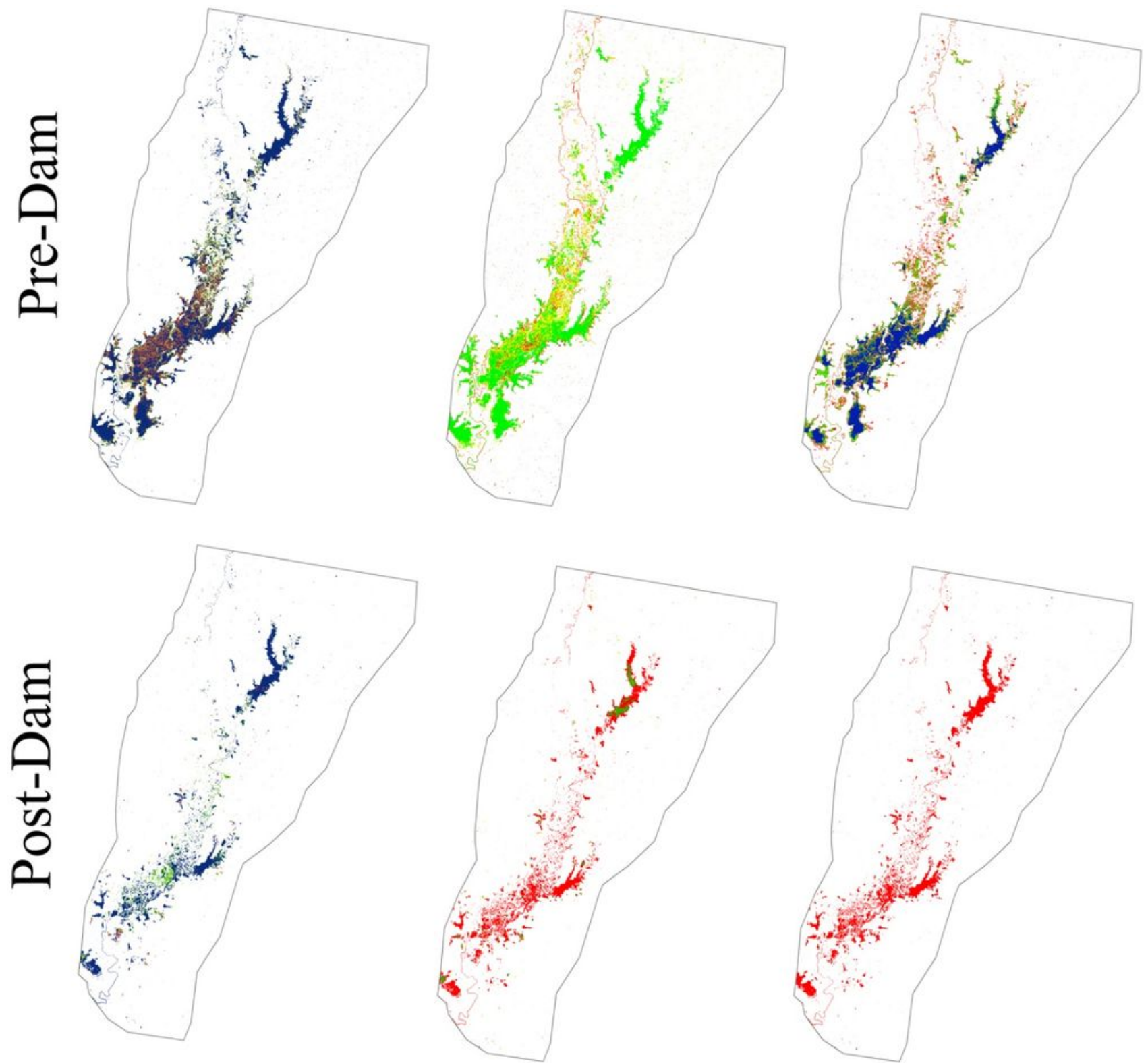

Water Presence

Frequency $(\%)$

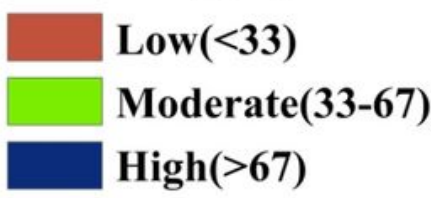

Hydroperiod(months)
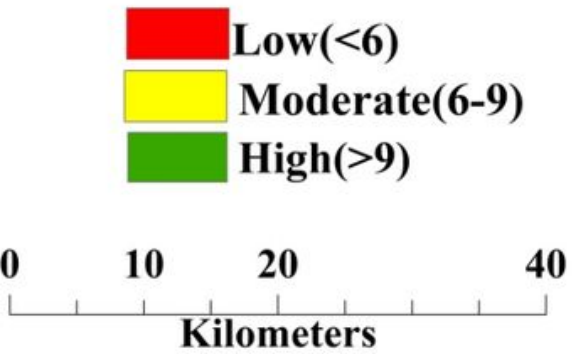

Water Depth(m)

Low (0.19 - 1.78)

Moderate(1.78 - 3.37)

High(3.37 - 4.96)

Figure 2

Hydrological attributes for pre-dam and post-dam periods 

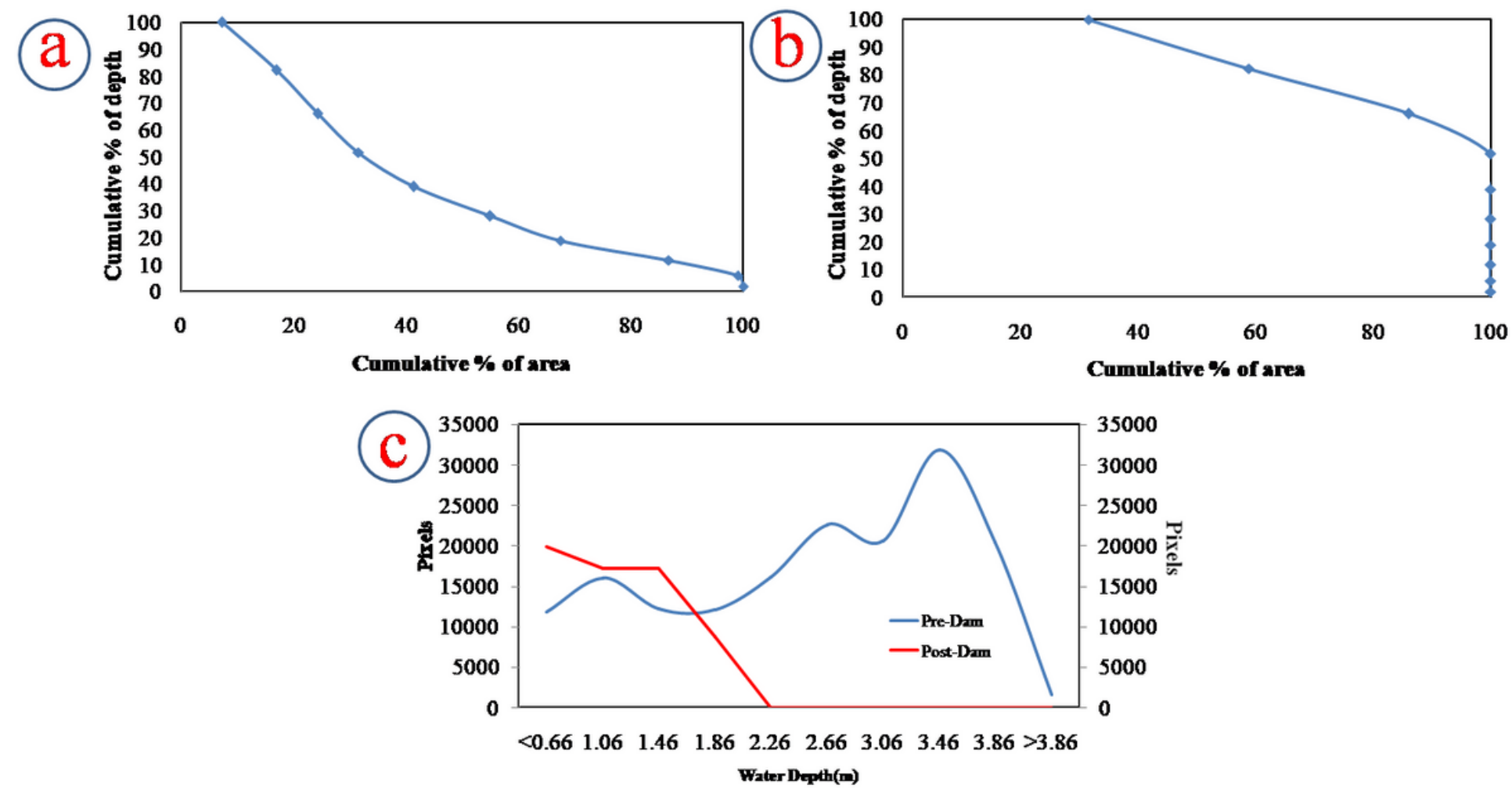

Figure 3

Depth-Area relation in the wetland of pre and post-dam periods using A. Cumulative \% hypsometric curve for pre-dam period, B. Cumulative \% hypsometric curve for post-dam period, C. Depth-Area frequency Curve 


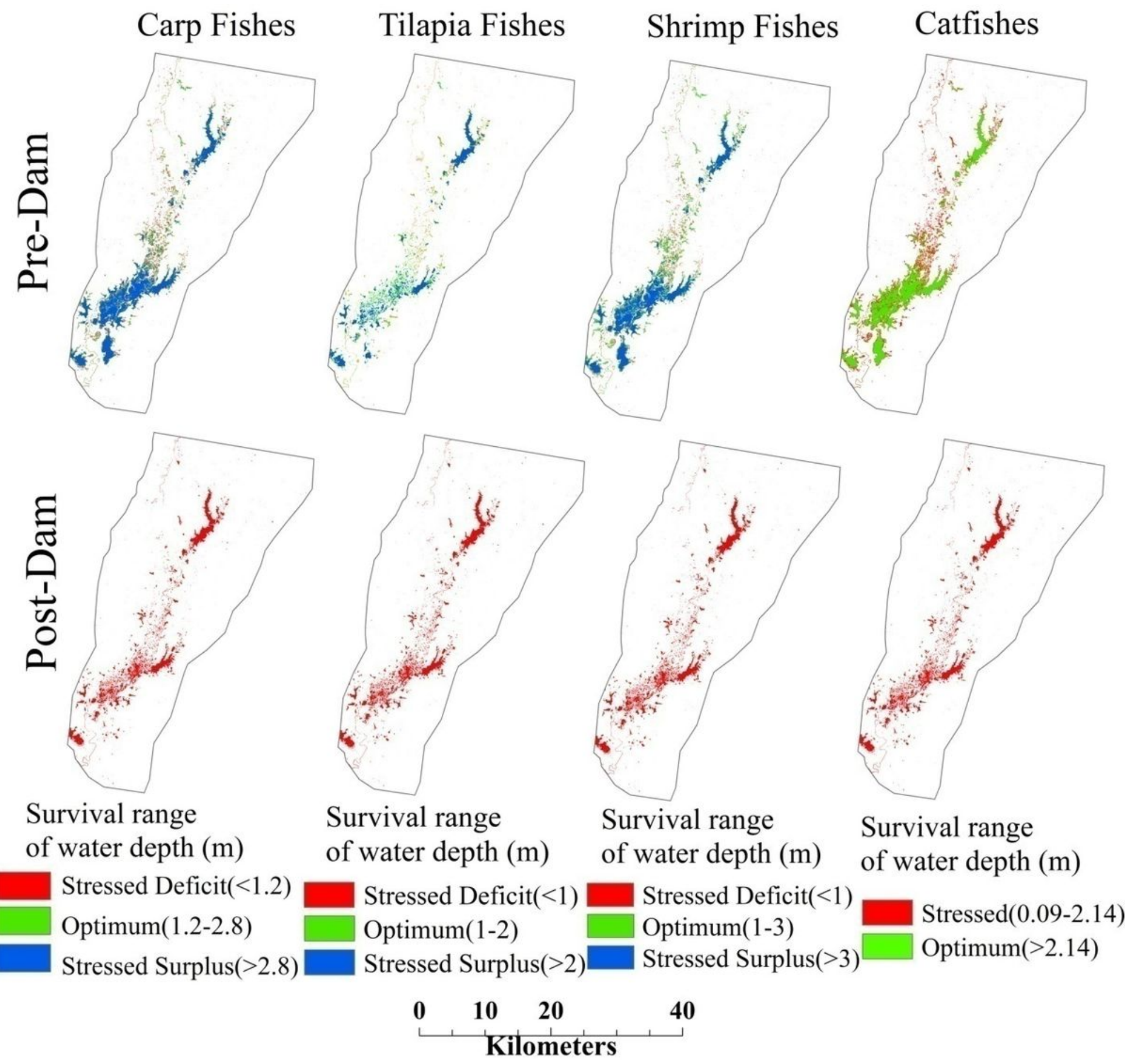

Figure 4

Survival range of water depth for some selected fishes in pre and post-dam periods 


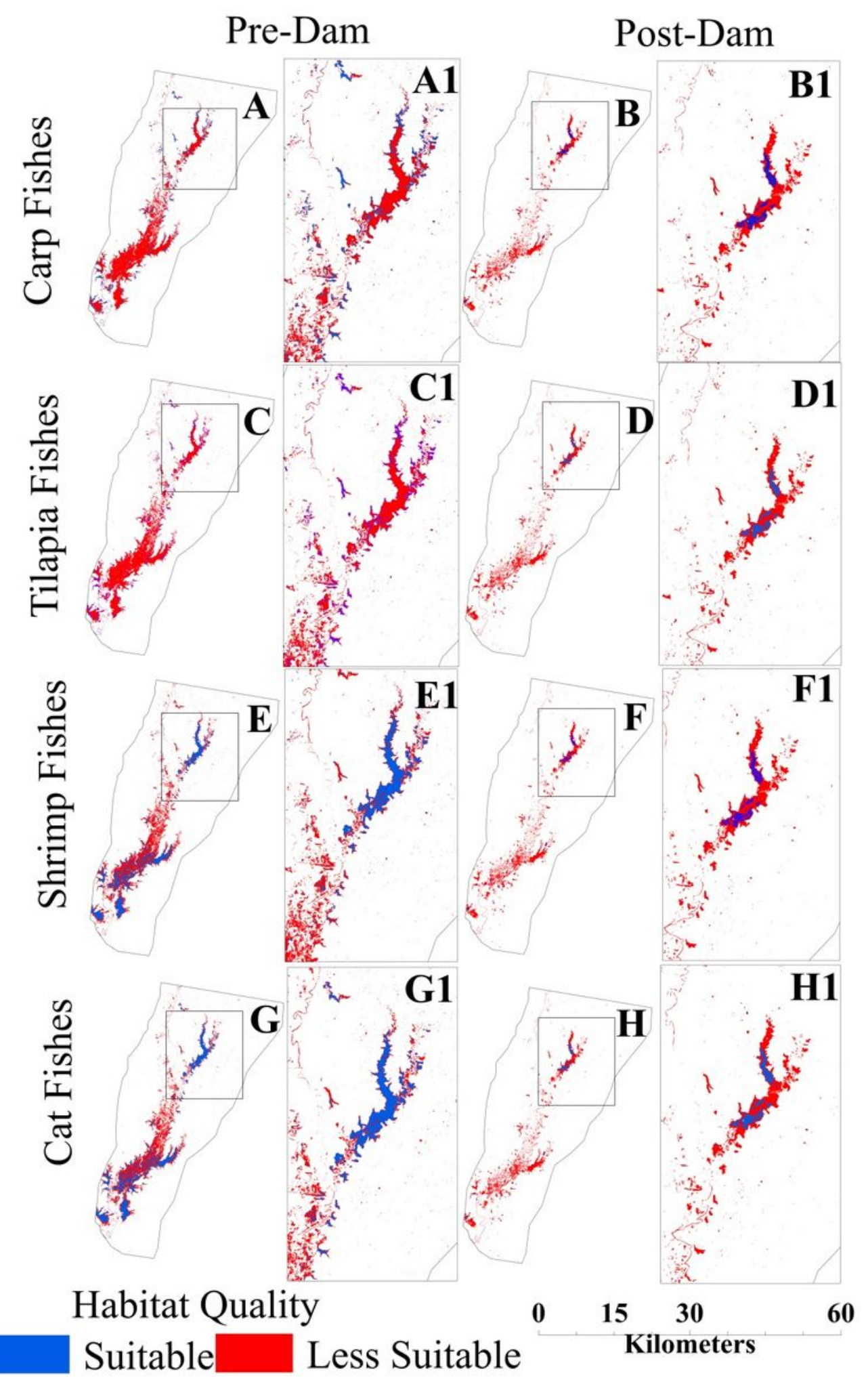

Figure 5

Rule-Based Decision tree driven fish habitat quality models of some selected fishes during pre and postdam periods. 